\title{
Study of Anticancer Activity of Pratensein and Pratensein Glycoside Isolated from Cuscuta kotchiana
}

\author{
Mandana Behbahani ${ }^{1}$ \& Mohaddeseh Moghaddam ${ }^{2}$ \\ ${ }^{1}$ Department of Biotechnology, Faculty of Advanced Sciences and Technologies, University of Isfahan - \\ 81746-73441 - Isfahan, Iran \\ ${ }^{2}$ Msc student of Microbial Biotechnology, University of Isfahan - 81746-73441 - Isfahan, Iran \\ Correspondence: Mandana Behbahani, Department of Biotechnology, Faculty of Advanced Sciences and \\ Technologies, University of Isfahan - 81746-73441 - Isfahan, Iran. Tel.: 98-311-793-4327.
}

Received: June 10, 2018

Accepted: June 29, 2018

Online Published: June 28, 2020

doi:10.5539/jmbr.v10n1p73

URL: https://doi.org/10.5539/jmbr.v10n1p73

\begin{abstract}
In the present paper, we demonstrate that extract of Cuscuta kotchiana is able to inhibit in vitro proliferation of two human breast cancer cell lines, MCF-7 and MDA-MB-231. The expression levels of p53, bcl-2, caspase-3 and bax genes at the mRNA and protein levels were evaluated using quantitative Real Time PCR and western blot analysis. The most active fractions of $C$. kotchiana were detected by NMR as pratensein and pratensein glycoside. The cytotoxic activity of pratensein glycoside was significantly more than pratensein. The expression level of bcl2 gene was decreased in cancer cells treated by both compounds at CC50 concentrations. But the expression levels of caspase-3, p53 and bax genes were increased in treated cancer cells. In conclusion, all the data demonstrated that the glycoside form of pratensein is important agent in inducing apoptosis in human breast cancer cells.
\end{abstract}

Keywords: Anticancer activity, pratensein, pratensein glycoside, apoptosis, bc12, p53

\section{Introduction}

An increasing number of research papers appoint that medicinal plants exhibit a variety of therapeutic properties and could provide health security to rural people in primary health care (Buonaguro et al., 2007). Among medicinal plants, Cuscuta species appear to be relevant. The genus Cuscuta (Convolvulaceae family) also known as dodder is an obligate stem parasite. Cuscuta species cannot complete their life cycle without attachment to host plants and they are totally dependent on its host plant for assimilates, nutrients and water supply. The parasitic relationship of Cuscuta specious with its hosts has been subjected by numerous investigations (Cos et al., 2003 and De Clercq et al., 2009). About 270 species of Cuscuta have been reported throughout the world (Vermani et al., 2002 and Rates et al., (2001). Some specious of Cuscuta have been reported to have potent anti-cancer and anti-viral activities (De Clercq et al., 2009 and Alqasoumi et al., 2008). Cuscuta kotchiana is one of the most common species of Cuscuta (Vermani et al., 2002). It has broad geographical distribution and is one of the most damaging parasite worldwide (Singh et al., 2005; Wang et al., 2006). Cuscuta kotchiana is the most prevalent species in Iran. So in the present study, anti-cancer activity of $C$. kotchiana has been studied.

\section{Methodology}

\subsection{Plant Material}

The aerial parts of $C$. kotchiana were collected from University of Isfahan herbarium, Iran in Oct 2011. The plant material was carefully dried and powdered.

\subsection{Extraction and Isolation of Compounds}

Methanol extract (98\%) of dried parts of C. kotchiana were prepared. The extraction was done thrice at $40^{\circ} \mathrm{C}$. Then, the resulting liquid was collected, filtered and reduced through evaporation by a rotary evaporator (Stroglass, Italy) at $45^{\circ} \mathrm{C}$ and dried using a freeze dryer (Zirbus, Germany). Silica-gel column fractionation chromatography was carried out separately with the dried methanol extract of $C$. kotchiana. Dried methanol extract of C.kotchiana (6 g) was eluted with Chloroform: Aceton: Methanol: (10:0:0 - 0:0:10, v/v/v) and 100\% methanol. Fractions $1-23(0.20,0.24,0.2,0.25,0.23,0.25,0.21,0.28,0.22,0.25,0.20,0.23,0.24,0.21,0.23$, 
$0.24,0.23,0.22,0.25,0.2,0.25,0.21,0.20 \mathrm{~g}$ ) were obtained. Fraction 8 and 13 were found to have anti-cancer activity and were analyzed by NMR analysis.

\subsection{NMR Analysis}

NMR screening was used to approve structure of active compounds. ${ }^{1} \mathrm{H}$ NMR and ${ }^{13} \mathrm{C}$ NMR spectra were recorded on Bruker $500 \mathrm{MHz}$ spectrometer by use of $\mathrm{CDCl}_{3}$ as residual solvent with chemical shifts expressed in parts per million (ppm).

\subsection{Culture Medium and Cell Lines}

MCF-7 and MDA-MB-231 breast cell lines and Human embryonic kidney normal cell line (HEK-293T) were acquired from National Cell Bank of Pasture Institute, Tehran, Iran. Cell lines were cultured in Dulbecco's Modified Eagle Medium (DMEM) supplemented with 10\% heat-inactivated Fetal Bovine Serum (FBS), $100 \mathrm{U} / \mathrm{ml}^{2}$ penicillin and $100 \mu \mathrm{g} \mathrm{ml}{ }^{-}$streptomycin and $5 \mathrm{mM} \mathrm{L}^{-}$glutamine. The cell lines were cultured at $37{ }^{\circ} \mathrm{C}$ under 5\% CO2 condition. All reagents and cell culture media were purchased from Gibco Company (Germany).

\subsection{Cytotoxicity Assay}

Cellular toxicity of pratensein and pratensein glycoside on cultured cells was determined using MTT assay (Twenty man et al., 1987). $5 \times 10^{4}$ cells per well were cultured in 96-well plates and incubated for $2 \mathrm{~h}$. Then, cells were treated with different concentrations of extracts and incubated for $48 \mathrm{~h}$. Later, MTT solution $(25 \mu \mathrm{l}$ of $5 \mathrm{mg} / \mathrm{ml}$, Roche) was added to each well, and the plate was incubated for an additional $4 \mathrm{~h}$. Finally, the medium was removed and $150 \mu \mathrm{l}$ of DMSO was added to solubilize the formed formazan crystals. The amount of formazan crystal was determined by measuring the absorbance at $492 \mathrm{~nm}$ using a microplate spectrophotometer (Awareness Technology Inc., stat fax 2100). Then 50\% cell cytotoxic concentration (CC50) values for both extracts isolated from C. kotchiana was calculated. All assays were carried out in triplicate.

\subsection{Quantitative Real-Time Polymerase Chain Reaction Assay for p53, bcl-2, Caspase-3 and Bax}

Expression levels of four widely established apoptotic-related mRNAs, p53, bcl-2, caspase-3 and bax were analyzed using Real Time PCR assay as described (Suzuki et al., 1999 and Ni et al., 2006). Real Time PCR was performed to quantify the amount of mRNA in untreated and treated cells. MCF-7 and MDA-MB-231 cells were treated with pratensein and pratensein glycoside at CC50 concentration for 6 and 12-h periods. Total cellular RNA was isolated from the untreated and treated cells using the Tri-Pure Isolation Reagent (Roche, USA), according to the manufacturer's instructions. A PCR reaction mixture of $50 \mu$ containing $5 \mu \mathrm{lof} \mathrm{dH}_{2} \mathrm{O}, 25 \mu \mathrm{l}$ of Taq Man Universal PCR Master Mix, $5 \mu \mathrm{l}$ of forward primer, $5 \mu \mathrm{l}$ reverse primer, $5 \mu$ FAM- TAMRA probes, $0.5 \mu 1$ of reverse transcriptase, $2 \mu \mathrm{l}$ random hexmer and $2 \mu \mathrm{l}$ of purified RNA were used. Four pairs of primers were separately used to amplify the p53, bcl2 and caspase-3 and bax genes, the other pair for endogenous control gene, gapdh. The primers and probes have been shown in Table 1. Real-time PCR was carried out on Corbett Cycler. Cycling conditions were as follows: initial reverse transcription at $55^{\circ} \mathrm{C}$ for $45 \mathrm{~min}, 1$ cycle denaturation at $95^{\circ} \mathrm{C}$ with $10 \mathrm{~min}$ hold, followed by 40 cycles of $95^{\circ} \mathrm{C}$ with $15 \mathrm{~s}$ hold, annealing temperature at $60^{\circ} \mathrm{C}(\mathrm{p} 53, \mathrm{bcl} 2$, caspase-3 and gapdh) with a $60 \mathrm{~s}$ hold. A negative control was included in each run to access specificity of primers and possible contamination. Primers and probes were synthesized by Metabion Company (Germany). Gene expression was normalized to gapdh using the comparative $2^{-\Delta \Delta C T}$ method, with expression levels in the untreated control.

Table1. The primer and probe sequences used in real-time PCR assay

\begin{tabular}{ll}
\hline Gene & Sequence \\
\hline \multirow{2}{*}{ p3 } & Forward:5'-AGAGTCTATAGGCCCACCCC-3' \\
& Reverse: 5'-GCTCGACGCTAGGATCTGAC-3' \\
& Probe:5-FAM-TTGGGCAGTGCTCGCT-MGB-3 \\
bcl-2 & Forward:5'-TTCGATCAGGAAGGCTAGAGTT-3' \\
& Reverse:5'-TCGGTCTCCTAAAAGCAG GC-3' \\
& Probe:5'-(FAM)CCCAGAGCATCAGGCCGCCAC(TAMRA)-3' \\
gapdh & Forward:5'-CATGGGGAAGGTGAAGGTCGA-3' \\
& Reverse: 5'-TTGGCTCCCCCCTGCAAATGAG-3' \\
& Probe:5'-(JOE)CCGACTCTTGCCCTTCGAC(TAMRA)-3' \\
caspase-3 & Forward:5'-TGCGCTGCTCTGCCTTCT-3' \\
& Reverse:5'-CCATGGGTAGCAGCTCCTTC-3' \\
& Probe:5-FAM-AGCTTCTTCATTTGTGTGCTCCGCTTTCA(TAMRA)-3' \\
bax & 5'- CATGTTTCTGACGGCAACTTC -3' \\
& 5'- AGGGCCTTGAGCACCAGTTT-3' \\
& Probe:5'-(FAM) CCGGGTTGTCGCCCTTTTCTACTTTG(TAMRA)-3' \\
\hline
\end{tabular}




\subsection{Western Blot Analysis}

The expression levels of P53 and Caspase-3, Bcl-2 and Bax proteins in MCF-7 and MDA-MB-231 cells were assessed by western blot method as described by Fido et al. (1995). Both cells $\left(5 \times 10^{6} \mathrm{cells} / \mathrm{ml}\right)$ were treated with pratensein and pratensein glycoside at CC50 concentrations for $48 \mathrm{~h}$ at $37^{\circ} \mathrm{C}$. Cells were lysed with $10 \mu \mathrm{l}$ of lyses buffer $(120 \mathrm{mmol} / \mathrm{L}$ Tris- $\mathrm{HCl}, 2 \mathrm{mmol} / \mathrm{L}$ N-ethylmaleimide, $2 \mathrm{mmol} / \mathrm{L}$ phenylmethyl sulfonylfluoride, $4 \%$ sodium dodecylsulfate, $4 \%$ dithiothreitol, $20 \%$ glycerol, $0.01 \%$ bromophenol blue, $2 \mathrm{~mol} / \mathrm{L}$ urea and $10 \mathrm{mmol} / \mathrm{L}$ $\mathrm{Na}-\mathrm{EDTA}$ at $\mathrm{pH}=6.8$. Cell lysates were centrifuged at $16000 \mathrm{rpm} / \mathrm{min}$ for $20 \mathrm{~min}$ at $4{ }^{\circ} \mathrm{C} .50 \mu \mathrm{g}$ of each sample was separately resolved by SDS-PAGE and move onto a nitrocellulose membrane overnight at $30 \mathrm{~mA}$. Membranes were blocked with $2 \%$ BSA diluted in PBS for $1 \mathrm{~h}$ at $37^{\circ} \mathrm{C}$. Membranes were incubated with saturating concentration of primary antibody (anti-P53; anti-Caspase-3, anti-Bcl2, anti-Bax) for $1 \mathrm{~h}$ under gentle agitation. The blots were washed three times and incubated with horse reddish peroxdase-conjugated anti-mouse IgG antibody for $1 \mathrm{~h}$ at $37^{\circ} \mathrm{C}$. Diaminobenzidine reagent was used to develop the immunoblots.

\subsection{Statistical Analysis}

Data from five independent experiments are presented as mean $\pm \mathrm{SD}$. The CC50 values were calculated by Microsoft Excel 2003. One-way analysis of variance (ANOVA) test was used to assess significance between the test sample and solvent control. P value $<0.05$ was considered to be statistically significant.

\section{Results}

\subsection{NMR Analysis}

The two active fractions obtained from C. kotchiana were fractions 8 and 13 which determined by NMR as pratensein and pratensein glycoside.

\section{Pratensein:}

${ }^{1} \mathbf{H}_{\text {NMR }}\left(\mathbf{C D C l}_{3}, \mathbf{4 0 0} \mathbf{M H z}\right): \delta=8.28(\mathrm{~s}, 1 \mathrm{H}), 7.34(\mathrm{~d}, 1 \mathrm{H}, J=1.8 \mathrm{~Hz}), 7.02\left(\mathrm{dd}, 1 \mathrm{H}, J_{I}=7.8, J_{2}=1.8 \mathrm{~Hz}\right), 6.88$ $(\mathrm{d}, 1 \mathrm{H}, J=8.4 \mathrm{~Hz}), 6.28(\mathrm{~d}, 1 \mathrm{H}, J=1.8 \mathrm{~Hz}), 6.16(\mathrm{~d}, 1 \mathrm{H}, J=1.8 \mathrm{~Hz}), 5.42(\mathrm{~s}, \mathrm{OH}), 3.81(\mathrm{~s}, 3 \mathrm{H}) .{ }^{13} \mathbf{C N M R}$ (CDCl, 100 MHz): $\delta=181.32,166.43,162.80,160.02,154.58,149.46,148.01,124.86,123.75,122.79,116.81$, $112.94,105.85,98.82,94.02,56.19$.

\section{Pratensein 7-O-glycoside:}

${ }^{1} \mathbf{H}$ NMR $\left(\mathbf{C D C l}_{3}, \mathbf{4 0 0} \mathbf{M H z}\right): \delta=8.27(\mathrm{~s}, 1 \mathrm{H}), 7.32(\mathrm{~d}, 1 \mathrm{H}, J=1.8 \mathrm{~Hz}), 7.02\left(\mathrm{dd}, 1 \mathrm{H}, J_{l}=7.8, J_{2}=1.8 \mathrm{~Hz}\right), 6.88$ $(\mathrm{d}, 1 \mathrm{H}, J=8.4 \mathrm{~Hz}), 6.26(\mathrm{~d}, 1 \mathrm{H}, J=1.8 \mathrm{~Hz}), 6.16(\mathrm{~d}, 1 \mathrm{H}, J=1.8 \mathrm{~Hz}), 5.36(\mathrm{~s}$, phenolic $\mathrm{OH}), 4.87(\mathrm{~d}, 1 \mathrm{H}, J=7.3$ $\mathrm{Hz}), 4.79\left(\mathrm{dd}, 1 \mathrm{H}, J_{I}=9.2, J_{2}=8.3 \mathrm{~Hz}\right), 4.38(\mathrm{t}, 1 \mathrm{H}, J=7.5 \mathrm{~Hz}), 3.90(\mathrm{~m}, 1 \mathrm{H}), 3.86(\mathrm{~s}, 3 \mathrm{H}), 3.76\left(\mathrm{dd}, 1 \mathrm{H}, J_{I}=\right.$ $\left.9.7 \mathrm{~Hz}, J_{2}=2.1 \mathrm{~Hz}\right), 3.72(\mathrm{~d}, 2 \mathrm{H}, J=11.8 \mathrm{~Hz}), 3.60(\mathrm{~s}$, glycoside $\mathrm{OH})$.

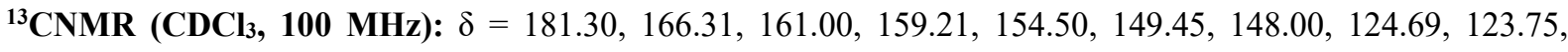
$122.79,116.81,112.94,105.85,98.58,98.13,92.62,78.45,76.11,72.32,69.81,61.51,56.17$.

\subsection{Cytotoxicy Assay}

Different fractions of $C$. kotchiana at $100 \mu \mathrm{g} / \mathrm{ml}$ were tested for cytoxicity against MCF-7 and MDA-MB-231 cell lines. Results showed that pratensein and pratensein 7-O-glycoside potentially inhibited viability of MCF-7 and MDA-MB-231 cell lines. Cytotoxic activity of these two extracts were further tested at different concentrations $(2.5,5,10,25,50,100,150,200 \mu \mathrm{g} / \mathrm{ml})$. As shown in Fig. 1, cytotoxic activities of both extracts are dose-dependent. The CC50 values of pratensein and pratensein 7-O-glycoside were determined around 100 and $8.5 \mu \mathrm{g} / \mathrm{ml}$ for MCF-7 cells, 125 and $23 \mu \mathrm{g} / \mathrm{ml}$ for MDA-MB 231 cells respectively. The results showed that cytotoxic activity of pratensein 7-O-glycoside on MCF7 and MDA-MB 231 cells was more than pratensein. The results also demonstrated that cytotoxic activity of these extracts on both cancer cells were significantly more than HEK-293 cells. 

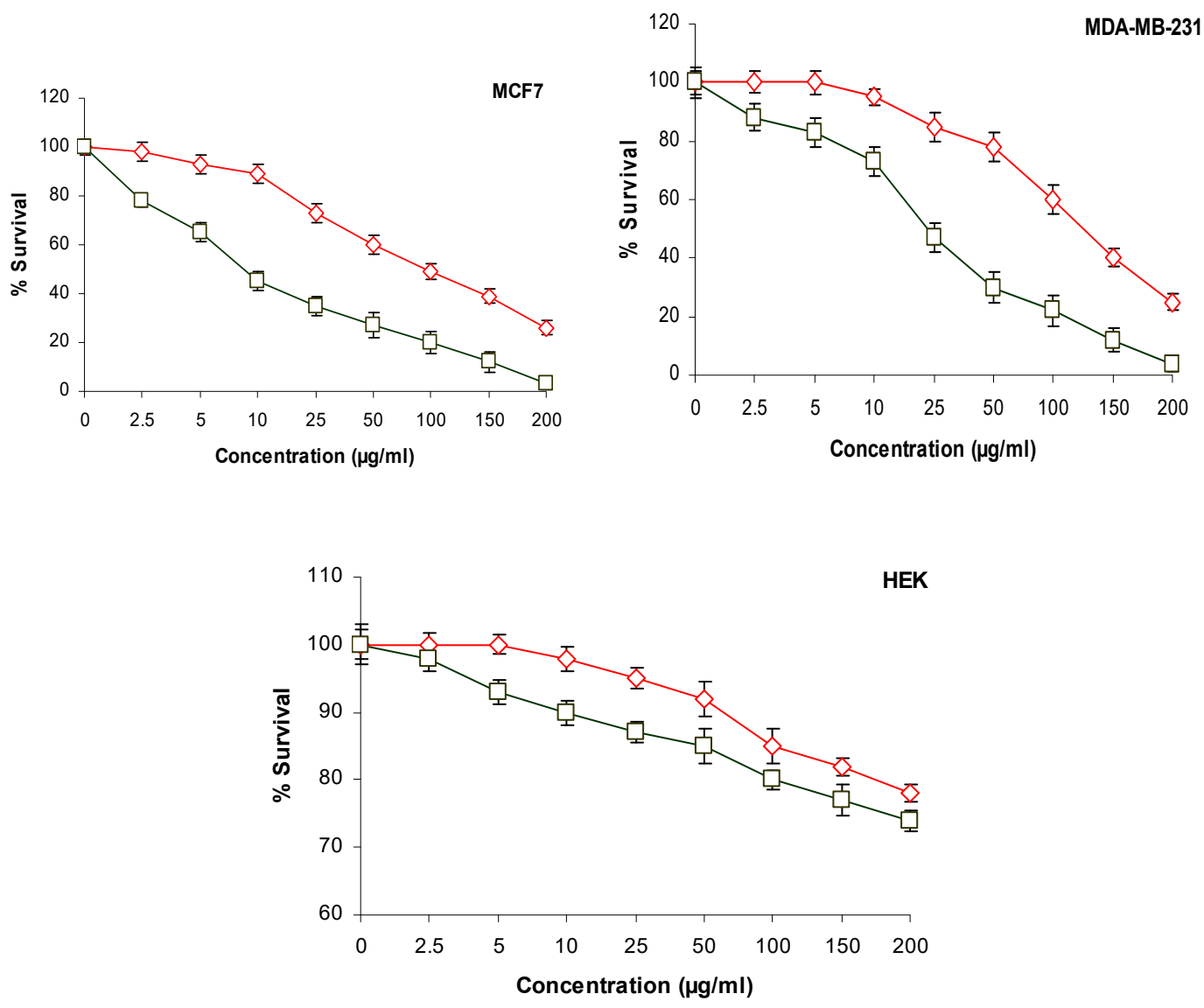

Figure 1. Cytotoxic activity of pratensein $(\diamond)$ and pratensein glycoside $\square$ against MCF7, MDA-MB-231 and HEK cell lines. CC50 values of pratensein and pratensein 7-O-glycoside were calculated around 100 and 8.5 $\mu \mathrm{g} / \mathrm{ml}$ for MCF-7 cells, 125 and $23 \mu \mathrm{g} / \mathrm{ml}$ for MDA-MB 231 cells respectively. Each value is the result of mean \pm

SD of three independent experiments. P value $<0.05$ was considered to be statistically significant.

\subsection{Expression Level of Apoptosis-Related Genes}

The relative quantification values of $\mathrm{p} 53$ and bcl-2, bax and caspase- 3 genes in MCF7 and MDA-MB 231 cells which was induced by pratensein and pratensein 7-O-glycoside calculated based on the $2^{-\Delta \Delta \mathrm{Ct}}$. Figures 2 and 3 showed that the expression levels of $\mathrm{p} 53$ and bcl 2 respectively increased and decreased in cells treated with both extracts compared to untreated cells. The expression level of p53 and bcl 2 in both breast cancer cells treated with extracts was time dependent. The strongest relative expression level of $\mathrm{p} 53$ after $12 \mathrm{~h}$ incubation, normalized to gapdh, was increased in MDA-MB 231 and MCF-7 cells treated with pratensein 7-O-glycoside up to 7 and 9 folds respectively (Fig. 2). Figure 3 indicated that the lowest relative expression level of bcl-2 was obtained in MCF-7 and MDA-MB 231 cells treated with pratensein and pratensein 7-O-glycoside up to 1 and 0.9 folds compared to control (1.8 fold). The relative expression of caspase-3 in MDA-MB-231 cancer cells treated with these two extracts was also increased as time-dependent to reach the maximum level at $12 \mathrm{~h}$ after stimulation. The maximum relative expression of caspase-3 was determined up to 5-7 folds in MDA-MB-231 cell line (Fig. 4). The absence of caspase-3 in MCF-7 cell leads to lack of any gene expression in treated and untreated cells (data not shown). The relative expression of bax in MDA-MB-231 and MCF7 cancer cells treated with both extracts was increased to reach the maximum of 7 to 8 folds at $12 \mathrm{~h}$ after stimulation. 

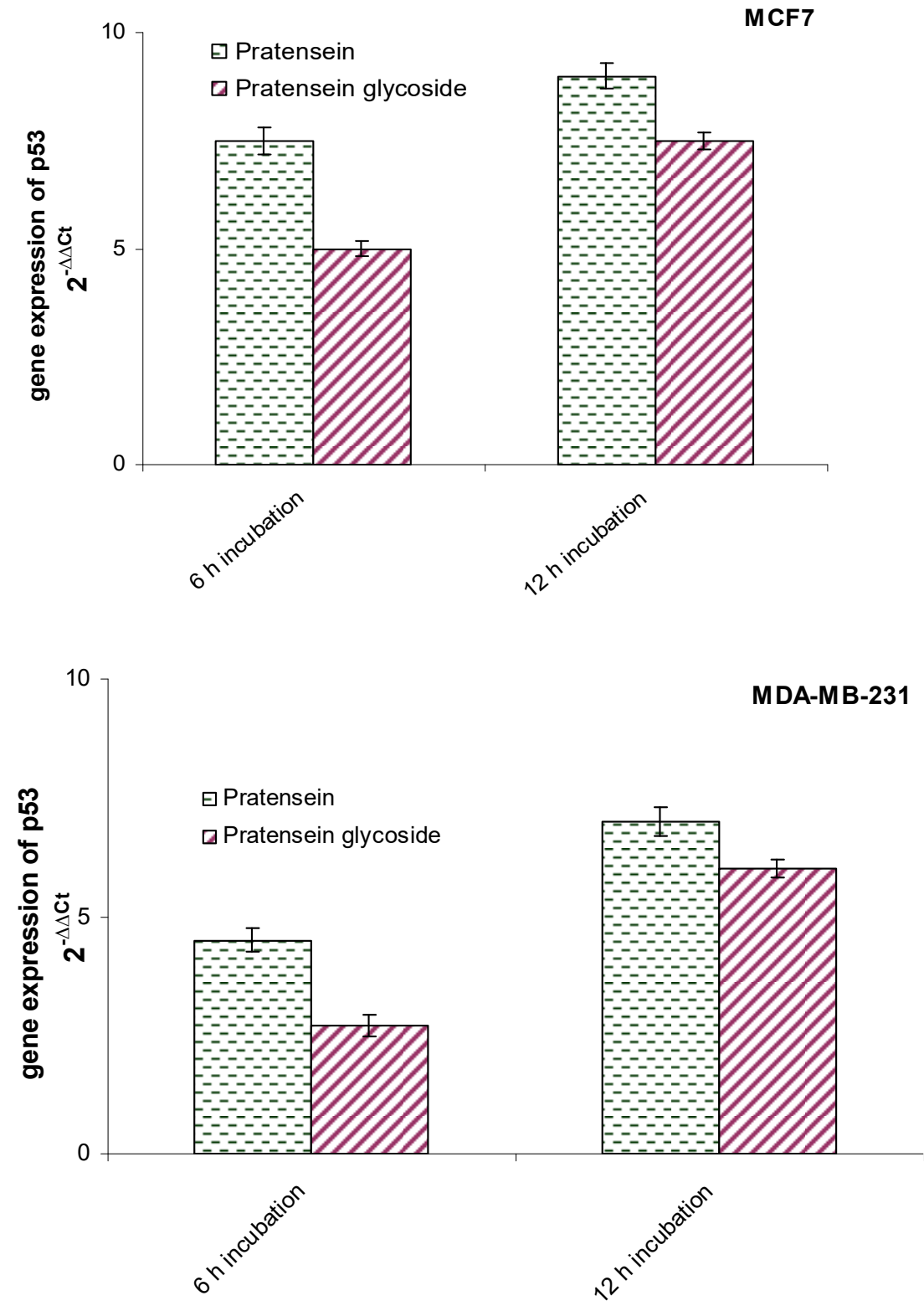

Figure 2. Changes in p53 mRNA expression in MCF7 and MDA-MB231 cells after treatment with pratensein $(\diamond)$ and pratensein glycoside $(\square)$ at CC50 concentration for 6 and $12 \mathrm{~h}$, in comparison with control cells. Detection and quantification of p53 mRNA in total cellular RNA was performed by RT-PCR. The value of $2-\Delta$ $\Delta \mathrm{Ct}$ represents the expression of the $\mathrm{p} 53$ gene in treated cells normalized to gapdh relative to the normalized expression of $\mathrm{p} 53$ gene in control cells. $\mathrm{P}$ value $<0.05$ was considered significant. 

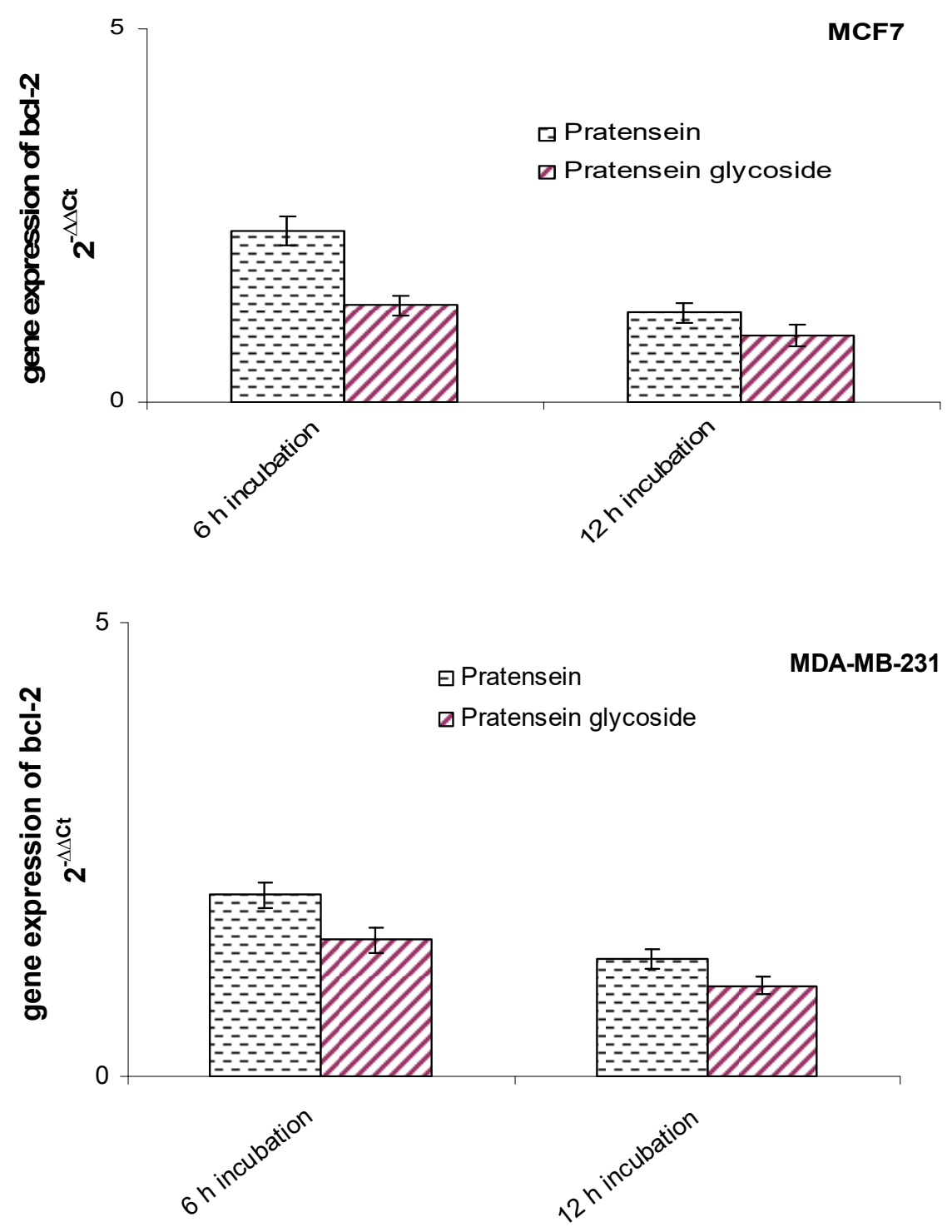

Figure 3. Changes in bcl2 mRNA expression in MCF7 and MDA-MB231 cells after treatment with pratensein $(\diamond)$ and pratensein glycoside $(\square)$ for 6 and $12 \mathrm{~h}$, in comparison with control cells. Detection and quantification of caspase-3 mRNA in total cellular RNA was performed by RT-PCR. The value of $2-\Delta \Delta C$ t represents the expression of the caspase- 3 gene in treated cells normalized to gapdh relative to the normalized expression of caspase-3 gene in control cells. 


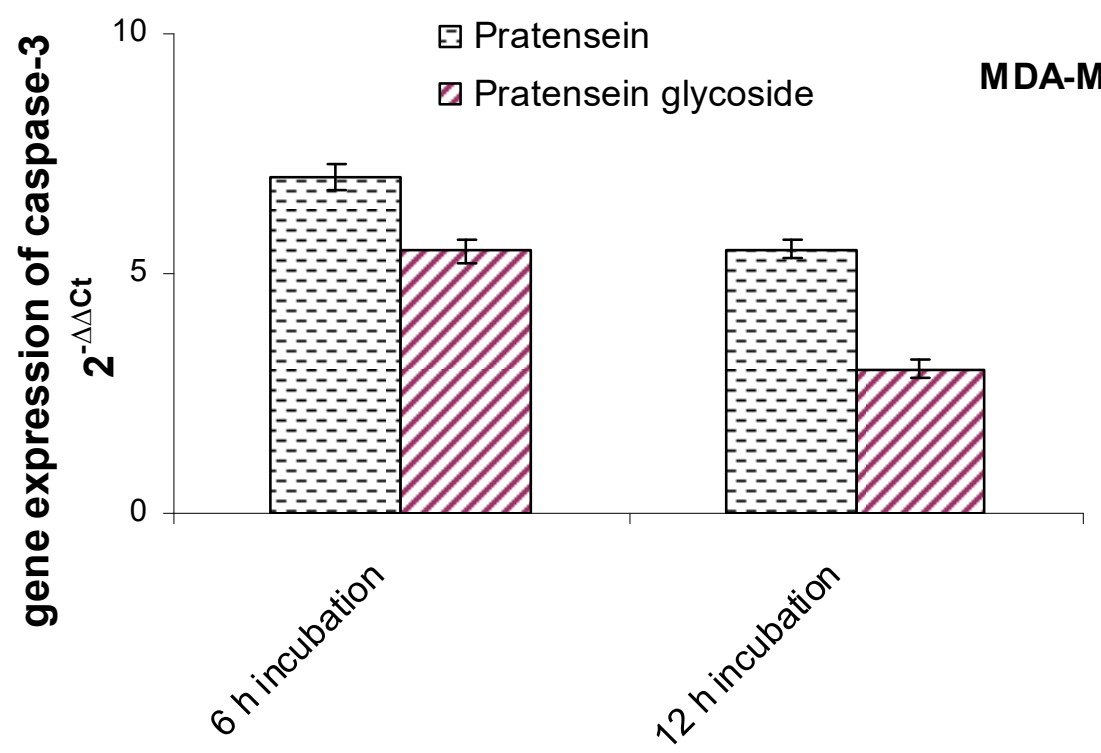

Figure 4. Changes in caspase-3 mRNA expression in MDA-MB231 cells after treatment with pratensein $(\diamond)$ and pratensein glycoside ( $\square$ ) for 6 and $12 \mathrm{~h}$, in comparison with control cells. Detection and quantification of caspase-3 mRNA in total cellular RNA was performed by RT-PCR. The value of $2-\Delta \Delta C$ t represents the expression of the caspase- 3 gene in treated cells normalized to gapdh relative to the normalized expression of caspase-3 gene in control cells.

\subsection{Western Blot Analysis}

The expression level of Bcl2, Bax and P53 proteins in MCF7 and MDA-MB23 cells treated with pratensein and pratensein glucoside along with $\beta$-actin as an internal control are shown by western blotting analysis. p53 and bax genes expressed respectively 53-kda and 21-kda proteins on western blotting. MDA and MCF7 cells also encode a 32-kDa and 24-kda proteins whose associate with Caspase-3 and Bcl2 proteins. As shown in Fig. 6, Western blot analysis showed the increase in band intensity of P53 and Bax proteins in MCF7 and MDA cells when compared to the internal control $\beta$-actin. Caspase- 3 was also increased in MDA cells compared to $\beta$-actin. The absence of caspase-3 gene in MCF-7 cell leads to lack of any Caspase- 3 protein in treated and untreated cells. Bcl2 protein was decreased in cancer cells treated by both compounds at CC50 concentrations.

\section{Discussion}

In this study, pratensein and pratensein glucoside isolated from C. kotchiana were considered as anticancer compounds. Pratensein is a member of the flavonoid family which found in various plants such as Trifolium pratense (Wong et al., 1963). There are reports on biological activities of pratensein including antioxidant and anti-inflammatory effects (Chen et al., 2008). The cytotoxic activity of pratensein and its glycoside derivate has been report here for the first time. Our findings are in agreement with some previous studies showing that some flavones isolated from medicinal plants are able to diminish the growth of breast cancer cells (Rodgers et al., 1998 and Dolečková et al., 2012). In the present study, we have presented the antitumor effects of pratensein and pratensein glucoside in breast cancer cells through induction of Caspase-3, Bax and P53 expression levels and inhibition of Bcl 2 activation in a time dependent manner. Most of the drugs currently used to treat cancer patients exert their anti-tumor activity through Caspase-3 and Bcl-2 mediated pathways. Therefore, the development of effective drugs which can reactivate wild-type P53, Bax and Caspase-3 is an attractive therapeutic strategy (Sano et al., 1997 and Issaeva et al., 2004). The previous results demonstrated that some isoflavone could induce apoptosis in cancer cells through the alteration of $\mathrm{Bax} / \mathrm{Bcl} 2$ ratio, which associated with the release of cytochrome $\mathrm{C}$ and induction of apoptotic protease activating factor-1 (Apaf-1) (Chew et al., 2003 and kim et al., 1998). The present results also showed that the cytotoxic activity of pratensein glycoside was significantly more than pratensein. These observations indicated pratensein glycoside have a good potential to be used as anticancer agent 
in patient. Nevertheless, further studies are needed to verify the molecular mechanism of pratensein glycoside on cancer cells.

\section{Conclusion}

Based on the findings of this study, it can be concluded that pratensein glycoside isolated from C. kotchiana is a new potential drug candidate for in vivo testing of patients with cancer.

\section{Acknowledgments}

This work was supported by the grant from University of Isfahan, Iran.

\section{References}

Alqasoumi, S. I., Al-Rehaily, A. J., AlSheikh, A. M., \& Abdel-Kader, M. S. (2008). Evaluation of the hepatoprotective effect of Ephedra foliate, Alhagi maurorum, Capsella bursa-pastoris and Hibiscus sabdariffa against experimentally induced liver injury in rats. Natural Product Sciences, 14(2), 95-99.

Buonaguro, L., Tornesello, M. L., \& Buonaguro, F. M. (2007). Human immunodeficiency virus type 1 subtype distribution in the worldwide epidemic: pathogenetic and therapeutic implications. Journal of virology, 81(19), 10209-10219.

Chen, H. Q., Wang, X. J., Jin, Z. Y., Xu, X. M., Zhao, J. W., \& Xie, Z. J. (2008). Protective effect of isoflavones from Trifolium pratense on dopaminergic neurons. Neuroscience Research, 62(2), 123-130.

Chew, B. P., Brown, C. M., Park, J. S., \& Mixter, P. F. (2003). Dietary lutein inhibits mouse mammary tumor growth by regulating angiogenesis and apoptosis. Anticancer research, 23(4), 3333-3339.

Cos, P., Berghe, D. V., Bruyne, T. D., \& Vlietinck, A. J. (2003). Plant substances as antiviral agents: An update (1997-2001). Current Organic Chemistry, 7(12), 1163-1180.

Dolečková, I., Rárová, L., Grúz, J., Vondrusová, M., Strnad, M., \& Kryštof, V. (2012). Antiproliferative and antiangiogenic effects of flavone eupatorin, an active constituent of chloroform extract of Orthosiphon stamineus leaves. Fitoterapia, 83(6), 1000-1007.

De Clercq, E. (2009). Anti-HIV drugs: 25 compounds approved within 25 years after the discovery of HIV. International journal of antimicrobial agents, 33(4), 307-320.

Fido, R. J., Tatham, A. S., \& Shewry, P. R. (1995). Western blotting analysis. In Plant Gene Transfer and Expression Protocols (pp. 423-437). Totowa, NJ: Springer.

Issaeva, N., Bozko, P., Enge, M., Protopopova, M., Verhoef, L. G., Masucci, M., ... \& Selivanova, G. (2004). Small molecule RITA binds to p53, blocks p53-HDM-2 interaction and activates p53 function in tumors. Nature medicine, 10(12), 1321.

Kim, J. M., Araki, S., Kim, D. J., Park, C. B., Takasuka, N., Baba-Toriyama, H., ... \& Tanaka, Y. (1998). Chemopreventive effects of carotenoids and curcumins on mouse colon carcinogenesis after 1, 2-dimethylhydrazine initiation. Carcinogenesis, 19(1), 81-85.

Ni, I. B. P., Lim, P., Balraj, P., Hang, E. S. U., \& Zakaria, Z. (2006). Quantitative analysis of the expression of p53 gene in colorectal carcinoma by using real-time PCR. Tropical biomedicine, 23(1), 53-59.

Rates, S. M. K. (2001). Plants as source of drugs. Toxicon, 39(5), 603-613.

Rodgers, E. H., \& Grant, M. H. (1998). The effect of the flavonoids, quercetin, myricetin and epicatechin on the growth and enzyme activities of MCF7 human breast cancer cells. Chemico-Biological Interactions, 116(3), 213-228.

Sano, H., Kawahito, Y., Wilder, R. L., Hashiramoto, A., Mukai, S., Asai, K., ... \& Hla, T. (1995). Expression of cyclooxygenase-1 and-2 in human colorectal cancer. Cancer Research, 55(17), 3785-3789.

Singh, I. P., Bharate, S. B., \& Bhutani, K. K. (2005). Anti-HIV natural products. Current science, 269-290.

Strong Jr, E. K., \& Uhrbrock, R. S. (1923). Bibliography on job analysis. L. Outhwaite (Series Ed.), Personnel Research Series, 1, 140-146.

Suzuki, K., Kazui, T., Yoshida, M., Uno, T., Kobayashi, T., Kimura, T., ... \& Sugimura, H. (1999). Drug-induced apoptosis and p53, BCL-2 and BAX expression in breast cancer tissues in vivo and in fibroblast cells in vitro. Japanese Journal of Clinical Oncology, 29(7), 323-331.

Twentyman, P. R., \& Luscombe, M. (1987). A study of some variables in a tetrazolium dye (MTT) based assay for cell growth and chemosensitivity. British Journal of Cancer, 56(3), 279. 
Vermani, K., \& Garg, S. (2002). Herbal medicines for sexually transmitted diseases and AIDS. Journal of Ethnopharmacology, 80(1), 49-66.

Wang, R. R., Gu, Q., Yang, L. M., Chen, J. J., Li, S. Y., \& Zheng, Y. T. (2006). Anti-HIV-1 activities of extracts from the medicinal plant Rhus chinensis. Journal of Ethnopharmacology, 105(1), 269-273.

Wong, E. (1963). Synthesis of pratensein, 5, 7, 3'-trihydroxy-4'-methoxyisoflavone. Tetrahedron Letters, 4(3), 159-161.

\section{Copyrights}

Copyright for this article is retained by the author(s), with first publication rights granted to the journal.

This is an open-access article distributed under the terms and conditions of the Creative Commons Attribution license (http://creativecommons.org/licenses/by/4.0/). 